\title{
Self efficacy dan Openness terhadap Perilaku Kerja Inovatif pada Kementerian Dalam Negeri
}

\author{
Sukma Nurmala ${ }^{1}$, Selly Dian Widyasari ${ }^{2}$ \\ Jurusan Psikologi, Fakultas Ilmu Sosial dan Ilmu Politik, Universitas Brawijaya \\ Gedung A lantai 4 Fakultas Ilmu Sosial dan Ilmu Politik Universitas Brawijaya, Jalan Veteran, Kota Malang
}

Email: sukmanurmala@ub.ac.id ${ }^{1}$, sellydianpsi@ub.ac.id²

\begin{abstract}
Abstrak
Penelitian ini bertujuan untuk mengetahui pengaruh self efficacy dan openness terhadap perilaku kerja inovatif di Kementerian Dalam Negeri. Sampel yang digunakan dalam penelitian ini adalah 183 Aparatur Sipil Negara (ASN) yang bekerja Direktorat Jenderal Otonomi Daerah Kementerian Dalam Negeri Republik Indonesia (114 laki-laki dan 69 perempuan, usia rerata subjek 40 tahun). Penelitian ini merupakan penelitian kuantitatif dan menggunakan Skala individual innovative behavior untuk mengukur inovasi individu, skala Big Five Inventory (BFI) versi bahasa Indonesia untuk mengukur keterbukaan wawasan individu, dan Indonesian Adaptation of the General SelfEfficacy untuk mengukur kepercayaan individu atas rencana yang telah disusunnya. Analisis data yang digunakan adalah statistik parametrik dengan uji regresi linear berganda. Hasil analisis data penelitian ini menunjukkan bahwa self efficacy dan openess memiliki pengaruh yang signifikan terhadap perilaku kerja inovatif $\left(\mathrm{R}^{2}=0,709\right.$, Sig. $=0,000$ ). Dengan kata lain, kontribusi pengaruh variasi variabel independen (variabel self efficacy dan variabel openess) mampu menjelaskan sebesar 70,9\% variasi variabel dependen (perilaku kerja inovatif) di Kementerian Dalam Negeri. Temuan ini memperkuat penelitian lainnya yang menunjukkan bagaimana selfefficacy dan openness mempengaruhi perilaku kerja inovatif.
\end{abstract}

Kata kunci: openness; perilaku kerja inovatif; self-efficacy

\begin{abstract}
This study aims to determine the effect of self-efficacy and openness toward innovative work behavior in the Ministry of Home Affairs. The sample used in this study were 183 State Civil Servants who worked at the Directorate General of Otonomi Daerah at the Ministry of Home Affairs of the Republic of Indonesia (114 men and 69 women, $M=40$ years). This research is a quantitative study and uses the individual innovative behavior scale to measure individual innovation, the Indonesian version of the Big Five Inventory (BFI) scale to measure the openness of individual insights, and the Indonesian Adaptation of the General Self-Efficacy Scale to measure individual confidence in his/her plans. The data analysis used is parametric statistics with multiple linear regression tests. The results of the data analysis of this study indicate that self-efficacy and openess have a significant effect on innovative work behavior $\left(\mathrm{R}^{2}=0.709\right.$, Sig. $\left.=0.000\right)$. In other words, the contribution of the influence of the independent variables (variations in the independent variables used in this study (self-efficacy and openess variables) can explain $70.9 \%$ of the variation in the dependent variable (innovative work behavior) at the Ministry of Home Affairct innovaties. These findings strengthen other researches that show how selfefficacy and openness affect innovative work behavior.
\end{abstract}

Keywords: openness; innovative work behavior; self-efficacy

\section{PENDAHULUAN}

Saat ini kemampuan organisasi untuk terus berinovasi dalam produk, layanan, dan proses kerja menjadi penting. Etikariena dan Muluk (2014) menyatakan bahwa organisasi memiliki tuntutan yang semakin besar untuk terus berinovasi supaya mampu bertahan dan berkompetisi memenuhi kebutuhan pasar. Selain itu, organisasi juga mulai mempertimbangkan untuk memasukkan inovasi sebagai bagian dari visi misi yang ingin dicapai atau kompetisi yang wajib dipenuhi oleh pekerjanya. Organisasi harus dapat mendorong pekerjanya untuk dapat menciptakan inovasi di tempat kerja. De Jong dan Hartog (2010) menegaskan bahwa kemampuan individu untuk berinovasi di lingkungan kerja merupakan salah satu faktor penting 
dalam menciptakan inovasi di organisasi. Aktivitas kerja fisik dan kognitif menjadi perpaduan dalam mencapai tujuan pengembangan inovasi (Messman \& Mulder, 2012), sehingga kemauan dan kemampuan individu untuk berinovasi diperlukan untuk memastikan arus inovasi dalam organisasi tetap terjaga.

Kleysen dan Street (2001) mendefinisikan individual innovative behavior dengan mengacu pada West dan Farr (1989), berupa perilaku individu yang ditujukan untuk menciptakan, mengenalkan, dan menerapkan kebaruan yang menguntungkan di berbagai level organisasi. Kleysen dan Street (2001) menambahkan bahwa kebaruan bermanfaat yang menggambarkan individual innovative behavior tersebut meliputi ide produk baru serta perubahan dalam prosedur administratif dan penerapan ide baru untuk proses kerja yang bertujuan untuk meningkatkan efisiensi dan efektivitas kerja secara signifikan.

Janssen, Van de Vliert, dan West (2004) menyatakan bahwa perilaku kerja inovatif ini dikategorikan sebagai aset yang dimiliki organisasi dan memungkinkan organisasi untuk sukses di tengah lingkungan yang dinamis. Janssen (2000) menguraikan adanya tiga dimensi yang menjadi dasar munculnya perilaku kerja inovatif di tempat kerja, yaitu menciptakan ide (idea generation), berbagi ide (idea promotion), dan realisasi ide (idea realization). Menciptakan ide, terlihat dari bagaimana karyawan mampu menciptakan ide atau solusi baru sebagai pemecahan masalah atas temuannya mengenai permasalahan yang terjadi di tempat kerja. Sedang berbagi ide, digambarkan dari bagaimana karyawan berbagi ide atau solusi baru atas permasalahan yang terjadi dan memperoleh dukungan atau persetujuan dari rekan-rekan kerjanya. Selanjutnya, realisasi ide adalah saat ide atau solusi baru tersebut memiliki potensi untuk menjadi produk dan proses kerja yang nyata (dapat diterapkan di lingkungan kerjanya), sehingga nantinya dapat meningkatkan efisiensi kerja di tempat kerjanya.

Jansen dkk (2004) meninjau dari sisi internal pekerja bahwa perilaku kerja inovatif dikategorikan sebagai aset yang dimiliki organisasi yang memungkinkan organisasi untuk sukses di tengah lingkungan yang dinamis. Salah satu faktor yang berpengaruh pada kemampuan individu untuk berinovasi adalah kepribadian. Matzler dkk (2011) menyatakan bahwa kepribadian dimaknai sebagai kebiasaan individu dalam berpikir, merasa, mempersepsi, dan bereaksi terhadap dunia. Kepribadian banyak diteliti sebagai faktor yang berpengaruh terhadap berbagai perilaku organisasi, sikap, dan kinerja. Perilaku kerja inovatif ditemukan pada individu yang memiliki kepribadian openess karena mereka memiliki karakteristik suka menerima pengalaman baru dan perubahan (George \& Zhou, 2001), memiliki keingintahuan yang tinggi (Costa \& McCrae, 1992), dan senang berproses dalam menciptakan dan berbagi ide gagasan baru yang berpotensi untuk dikembangkan (Chen, Wu \& Chen., 2010).

Kesepakatan bersama diantara para ilmuwan psikologi tentang model kepribadian yang komprehensif dikenal dengan istilah big five personality model, terdiri dari lima traits kepribadian secara umum yaitu extraversion, conscientiousness, agreeableness, neuroticism, dan openness (Costa \& McCrae, 1988). Ramdhani (2012) menyatakan bahwa big five personality model adalah taksonomi kepribadian yang disusun berdasarkan pengelompokan kata-kata atau bahasa yang digunakan di dalam kehidupan sehari-hari. Pengelompokan ini dari ribuan ciri menjadi lima himpunan besar yang kemudian dikenal dengan istilah dimensi kepribadian.

openness atau openness to experience, dikenal juga dengan istilah keterbukaan merupakan dimensi yang erat kaitannya dengan keterbukaan wawasan dan orisinalitas ide. Individu yang terbuka cenderung siap menerima berbagai stimulus yang ada dengan sudut pandang yang terbuka. Individu yang terbuka senang dengan berbagai informasi baru, suka mempelajari sesuatu yang baru, dan pandai menciptakan aktivitas di luar kebiasaan yang ada (Ramdhani, 2012). Keterbukaan merujuk pada derajat imajinasi atau daya tarik individu. Keterbukaan juga 
merepresentasikan karakteristik kepribadian seperti rasa ingin tahu, kebaruan, sopan, estetika, sensitivitas, pemikiran yang mandiri, intelektual, dan kreatif (Abdullah, Omar, \& Panatik, 2016).

Keterbukaan ditemukan memiliki hubungan positif dengan innovative behavior (Olakitan, 2011), innovative performance pada karyawan (Hsieh, Hsieh, \& Wang, 2011), peningkatan self-efficacy (Judge, Jackson, Shaw, Scott \& Rich, 2007), dan tahapan idea generation serta idea promotion pada innovative behavior (Chen dkk., 2010). Individu dengan openness tinggi lebih suka menerima pengalaman baru dan perubahan yang merupakan elemen penting dalam proses inovasi dan temuan ini sejalan dengan penelitian terdahulu yang menghubungkan openness dengan kreativitas (George \& Zhou, 2001).

Faktor internal lain yang berpengaruh terhadap perilaku kerja inovatif adalah self-efficacy. Momeni, Ebrahimpour, dan Ajirloo (2014) menambahkan bahwa individu yang memiliki selfefficacy yang baik menunjukkan pemahamannya untuk mampu mengimplementasikan tugas yang diemban secara efektif. Selain itu, keyakinan diri individu terhadap kompetensi kerja dan kompetensi kreativitas yang dimilikinya mempengaruhi motivasi individu untuk terlibat langsung dalam suatu inovasi (Hammond, Neff, Farr, Schwall, \& Zhao, 2011). Turgut dan Sökmen (2018) menemukan bahwa individu yang memiliki level self-efficacy tinggi menunjukkan perilaku menantang dan beresiko seperti innovative work behaviors. Individu yang memiliki self-efficacy tinggi juga termotivasi secara intrinsik untuk sepenuhnya mengerahkan kemampuannya untuk terlibat dalam pekerjaannya, menaklukkan tantangan kerja secara mandiri (Michael, Hou, \& Fan, 2011) dan mengejar cita-citanya (Berry \& West, 1993).

Hal ini didukung oleh temuan Zahra, Ahmad, dan Waheed (2017) yang menyatakan bahwa karyawan yang memiliki self-efficacy yang tinggi cenderung menghasilkan, mempromosikan dan mengimplementasikan ide-ide baru. Sejalan dengan temuan Carmeli dan Schaubroeck (2007) yang menyatakan bahwa individu yang memiliki self-efficacy tinggi cenderung lebih berupaya untuk meningkatkan proses kerja, melakukan tugas yang menantang, dan mempraktekkan inovasi dalam pekerjaannya. Sebaliknya individu yang memiliki self-efficacy rendah cenderung tidak memiliki upaya untuk meningkatkan proses kerja dan melakukan tugas rutin sehari-hari.

Adapun tujuan penelitian ini adalah untuk melihat pengaruh self efficacy dan openess terhadap perilaku kerja inovatif pada Aparatur Sipil Negara (ASN) yang bekerja di Direktorat Jenderal Otonomi Daerah Kementerian Dalam Negeri Republik Indonesia, sebab perilaku inovatif di organisasi pemerintahan diperlukan guna meningkatkan kinerja birokrasi yang lebih baik. Hipotesis penelitian ini adalah self efficacy dan openess akan berpengaruh terhadap perilaku kerja inovatif. Hal ini diasumsikan bahwa semakin naik self efficacy, maka semakin meningkat perilaku kerja inovatif. Sejalan dengan semakin naik openness, maka semakin meningkat perilaku kerja inovatif.

\section{METODE}

Responden dalam penelitian ini menggunakan sampel Aparatur Sipil Negara (ASN) yang bekerja di Direktorat Jenderal Otonomi Daerah Kementerian Dalam Negeri Republik Indonesia dengan masa kerja minimal satu tahun. Bersedia untuk disertakan dalam penelitian ini yang dibuktikan dengan bentuk inform consent. Skala disebarkan secara online melalui tautan Google Form. Teknik pengambilan sampel yang digunakan adalah non-probability sampling dengan kriteria inklusi. Jumlah sampel $\mathrm{N}=183$ pegawai ASN (114 laki-laki dan 69 perempuan). Rerata usia subjek 40 tahun dengan jenjang pendidikan mulai tingkat SLTA/ Sederajat sampai dengan jenjang pendidikan S3. 
Terdapat tiga skala psikologi yang digunakan sebagai instrumen pengumpulan data dalam penelitian ini. Pertama, alat ukur Indonesian Adaptation of the General Self-Efficacy Scale yang dikembangkan oleh Born, Schwarzer, dan Jerusalem (1995) yang terdiri dari 10 item dan menggunakan skala Likert dengan interval empat (a four-point likert scale) yang terdiri dari tidak setuju (1), agak setuju (2), hampir setuju (3), dan sangat setuju (4). Scholtz dkk (2002) menyatakan bahwa nilai koefisien stabilitas (test re-test reliability) dalam penelitian longitudinal skala tersebut berkisar antara 0,47 hingga 0,75 . Nilai reliabilitas berkisar antara 0,76 hingga 0,90 karena skala tersebut telah diterjemahkan ke dalam 32 bahasa dan dipergunakan dalam penelitian di berbagai negara (cek di http://userpage.fuberlin.de/health/selfscal.htm). Hasil uji reliabilitas variabel self efficacy penelitian ini menunjukkan nilai Cronbach's Alpha sebesar 0,937. Tiga dimensi yang digunakan untuk mengukur self-efficacy dalam skala ini adalah level/ magnitude, generality, dan strength. Contoh bunyi item dalam skala ini adalah "Dalam situasi yang tidak terduga saya selalu tahu bagaimana saya harus bertingkah laku", "Saya dapat menghadapi kesulitan dengan tenang karena saya selalu dapat mengandalkan kemampuan saya", dan "Kalau saya menghadapi kesulitan, biasanya saya mempunyai banyak ide untuk mengatasinya".

Kedua, alat ukur Big Five Inventory (BFI) versi bahasa Indonesia yang diadaptasi oleh Ramdhani (2012) dan terdiri dari 10 item. Penulis hanya menggunakan dimensi openness yang memiliki nilai reliabilitas sebesar 0,79. Tiga dimensi yang digunakan untuk mengukur openness dalam skala ini adalah aesthetic sensitivity (sensitivitas ekstetika), intellectual curiosity (keingintahuan intelektual), dan creative imagination (daya khayal kreatif). Contoh bunyi item dalam skala ini adalah "Saya adalah orang yang sering mendapatkan ide baru", "Saya adalah orang yang suka penasaran dengan banyak hal yang berbeda", dan "Saya adalah orang yang berdaya cipta".

Ketiga, alat ukur individual innovative behavior yang dikembangkan oleh Kleysen dan Street (2001) dan terdiri dari 14 item. Nilai reliabilitas sebesar 0,95. Lima dimensi yang digunakan untuk mengukur perilaku kerja inovatif dalam skala ini adalah eksprolasi peluang (opportunity exploration), generativity, formative investigation, championing, dan application. Contoh bunyi item dalam skala ini adalah "Saya mencari peluang untuk meningkatkan proses kerja, teknologi, produk, layanan, atau hubungan kerja yang ada saat ini", "Saya menghasilkan ide atau solusi untuk mengatasi permasalahan", dan "Saya berusaha mengatasi kesalahan saat menerapkan pendekatan baru pada proses kerja, teknologi, produk, atau layanan yang ada".

Analisis data dalam penelitian ini menggunakan teknik analisis regresi linear berganda untuk melihat pengaruh dari dua variabel independen $\left(\mathrm{X}_{1}, \mathrm{X}_{2}\right)$ terhadap variabel dependen $(\mathrm{Y})$. Dua variabel independen yaitu self efficacy $\left(\mathrm{X}_{1}\right)$ dan openness $\left(\mathrm{X}_{2}\right)$, sedangkan satu variabel dependen yaitu perilaku kerja inovatif $(\mathrm{Y})$.

\section{HASIL}

Penelitian ini melibatkan 183 Aparatur Sipil Negara (ASN) yang bekerja di Direktorat Jenderal Otonomi Daerah Kementerian Dalam Negeri Republik Indonesia. Penjelasan mengenai demografi responden dalam penelitian ini diuraikan pada tabel 1 berikut:

Tabel 1.

Karakteristik Subjek

\begin{tabular}{llll}
\hline Karakteristik & Kategori & Jumlah & Persentase \% \\
\hline Jenis Kelamin & Laki-laki & 114 & 62.3 \\
& Perempuan & 69 & 37.7 \\
\hline Pendidikan Terakhir & SMA/Sederajat & 6 & 3.3
\end{tabular}




\begin{tabular}{llll} 
& S1 & 84 & 45.9 \\
& S2 & 91 & 49.7 \\
& S3 & 2 & 1.1 \\
\hline Golongan Kerja & Golongan II (Pengatur) & 1 & 0.5 \\
& Golongan III (Penata) & 145 & 79.3 \\
& Golongan IV (Pembina) & 37 & 20.2 \\
\hline
\end{tabular}

Berdasarkan tabel 1 diatas, dapat dilihat bahwa sebanyak 114 responden atau sebanyak $62,3 \%$ adalah Aparatur Sipil Negara (ASN) didominasi oleh laki-laki dan 69 responden atau $37,7 \%$ responden adalah perempuan. Berdasarkan tingkat pendidikan terakhir sebanyak 6 responden atau 3,3\% memiliki latar belakang pendidikan SMA/ Sederajat, 84 responden atau 45,9\% memiliki latar belakang pendidikan $\mathrm{S} 1,91$ responden atau 49,7\% memiliki latar belakang pendidikan S2, dan 2 responden atau 1,1\% memiliki latar belakang pendidikan S3. Jika dilihat dari golongan kerja sebanyak 1 responden atau $0,5 \%$ dengan golongan kerja II (Pengatur), 145 responden atau 79,3\% dengan golongan kerja III (Penata), dan 37 responden atau 20,2\% dengan golongan kerja IV (Pembina).

Analisis regresi pada penelitian ini telah melewati proses hasil uji asumsi klasik meliputi uji heteroskedastisitas, uji multikolinieritas, dan uji autokorelasi. Suatu model regresi dinyatakan bebas dari multikolinearitas jika mempunyai nilai Tolerance di atas 0,1 dan nilai VIF di bawah 10 (Ghozali, 2013). Pada $X_{1}$ (kepemimpinan transformasional) = 0,704 sampai dengan 1,421. Pada $\mathrm{X}_{2}$ (openness) $=0,564$ sampai dengan 1,774 . Pada $\mathrm{X}_{3}($ self-efficacy $)=0.618$ sampai dengan 1,617. Dari hasil di atas dapat diketahui nilai variance inflation factor (VIF) ketiga variabel yaitu $\mathrm{X}_{1}$ (kepemimpinan transformasional), $\mathrm{X}_{2}$ (openness), dan $\mathrm{X}_{3}$ (self-efficacy) < dari 10 dan nilai Tolerance $>0,1$, sehingga dapat disimpulkan bahwa antar variabel independen tidak terjadi persoalan multikolinearitas. Sedang untuk uji autokorelasi, nilai D-W sebesar 1,839. Pembanding menggunakan nilai signifikansi 5\%, jumlah sampel (n) $=183$, dan jumlah variabel $3(\mathrm{k}=3)$, maka di tabel $\mathrm{D}-\mathrm{W}$ akan diperoleh nilai dU sebesar 1,791. Karena nilai $\mathrm{D}-\mathrm{W}$ $=1,839>$ dari batas atas (dU) 1,791 dan kurang dari 4-1,791 (2,209), maka dapat disimpulkan bahwa tidak terdapat autokorelasi positif.

Tabel 2.

Hasil Uji F (Uji Simultan) Perilaku Kerja Inovatif

\begin{tabular}{llllll}
\hline Model 1 & Sum of Squares & df & Mean Square & F & Sig. \\
\hline Regresi & 7204.619 & 2 & 3602.309 & 218.867 & $.000^{\mathrm{b}}$ \\
Residual & 2962.605 & 180 & 16.459 & & \\
\hline
\end{tabular}

Dari hasil analisis diketahui bahwa hasil uji F regresi memiliki nilai sig. 0,000. Karena nilai sig. kurang dari $0,05(0,00<0,05)$, maka Ho ditolak yang berarti self efficacy dan openness secara simultan berpengaruh terhadap perilaku kerja inovatif pada Aparatur Sipil Negara (ASN) yang bekerja di Direkto rat Jenderal Otonomi Daerah Kementerian Dalam Negeri Republik Indonesia.

Tabel 3.

Tabel Koefisien

\begin{tabular}{llllll}
\hline Model & $\begin{array}{l}\text { Unstandardized } \\
\text { B }\end{array}$ & $\begin{array}{l}\text { Coefficients } \\
\text { Standart Error }\end{array}$ & $\begin{array}{l}\text { Standardized } \\
\text { Coefficients Beta }\end{array}$ & $\mathrm{t}$ & Sig. \\
\hline (Constant) & -6.500 & 2.352 & & -2.764 & 0.006 \\
Self Efficacy & 0.886 & 0.087 & 0.528 & 10.233 & 0.000 \\
Openness & 0.779 & 0.100 & 0.403 & 7.812 & 0.000 \\
\hline
\end{tabular}


Selanjutnya tabel 5 menemukan persamaan regresi linear berganda untuk dua prediktor yaitu $\mathrm{Y}=-6,5+0,886$ self efficacy $+0,779$ openness. Persamaan tersebut dapat dijelaskan sebagai berikut:

a) Konstanta sebesar -6,5; artinya jika self efficacy $\left(\mathrm{X}_{1}\right)$ dan openness $\left(\mathrm{X}_{2}\right)$ nilainya adalah 0 , maka innovative work behavior $(\mathrm{Y})$ nilainya adalah $-6,5$.

b) Koefisien regresi variabel self efficacy $\left(\mathrm{X}_{1}\right)$ sebesar 0,886 ; artinya jika variabel independen lain nilainya tetap dan self efficacy mengalami kenaikan 1\%, maka innovative work behavior (Y) akan mengalami peningkatan sebesar 0,886. Koefisien bernilai positif artinya terjadi hubungan positif antara self efficacy dan innovative work behavior (Y). Temuan ini dapat dimaknai bahwa semakin tinggi self efficacy maka semakin meningkat innovative work behavior (Y).

c) Koefisien regresi variabel openess $\left(\mathrm{X}_{2}\right)$ sebesar 0,779 ; artinya jika variabel independen lain nilainya tetap dan openess mengalami kenaikan $1 \%$, maka innovative work behavior (Y) akan mengalami peningkatan sebesar 0,779 . Koefisien bernilai positif artinya terjadi hubungan positif antara openess $\left(\mathrm{X}_{2}\right)$ dan innovative work behavior $(\mathrm{Y})$, semakin naik openess maka semakin meningkat innovative work behavior $(\mathrm{Y})$.

Kontribusi pengaruh variabel independen (variabel self efficacy dan variabel openness) secara simultan berpengaruh terhadap variabel innovative work behavior sebesar $70,9 \%$ atau variasi variabel independen yang digunakan dalam model (variabel self efficacy dan variabel openness) mampu menjelaskan sebesar $70,9 \%$ variasi variabel dependen (innovative work behavior), nilai signifikansi yang diperoleh sebesat $\mathrm{F}=0,000(<0,05), \mathrm{R}^{2}=0,709$ atau 70,9\%, dan $R=0,842$. Dengan demikian, persyaratan agar dapat memaknai nilai koefisien determinasi dalam analisis regresi linear berganda sudah terpenuhi dan hipotesis penelitian ini diterima.

\section{DISKUSI}

Hasil penelitian menunjukkan bahwa self efficacy dan openness memiliki pengaruh terhadap perilaku kerja inovatif. Hal tersebut mengindikasikan bahwa self efficacy dan openness ASN yang bekerja Direktorat Jenderal Otonomi Daerah Kementerian Dalam Negeri Republik Indonesia berperan terhadap perilaku kerja inovatif. Temuan ini sejalan dengan penelitian terdahulu Olakitan (2011) yang menyatakan bahwa kepribadian openess berhubungan positif dengan perilaku inovatif pekerjanya. Didukung juga oleh temuan Costa dan McCrae (1992) yang menyatakan bahwa individu dengan kepribadian openness yang tinggi cenderung lebih fleksibel dalam berpikir, memiliki rasa ingin tahu yang tinggi, dan memiliki sisi imaginatif. George dan Zhou (2001) juga menambahkan bahwa individu dengan kepribadian openness yang tinggi cenderung untuk lebih suka menerima pengalaman baru serta menyukai perubahan sebagai suatu elemen penting dalam proses inovasi. Dengan kata lain individu dengan kepribadian openness cenderung mengasah sisi keingintahuannya serta mampu memposisikan diri sesuai dengan dinamika kerja yang dihadapinya. Dari sisi self efficacy, karyawan yang memiliki self-efficacy tinggi cenderung menghasilkan, mempromosikan dan mengimplementasikan ide-ide baru (Zahra, Ahmad, \& Waheed, 2017), lebih berupaya untuk meningkatkan proses kerja, melakukan tugas yang menantang, dan mempraktekkan inovasi dalam pekerjaannya (Carmeli \& Schaubroeck, 2007), serta termotivasi secara intrinsik untuk sepenuhnya mengerahkan kemampuannya sehingga mampu terlibat dalam pekerjaannya serta menaklukkan tantangan kerja secara mandiri (Michael, Hou, \& Fan, 2011).

Jika dicermati nilai proporsi varians self efficacy dan openness terhadap perilaku kerja inovatif yang didapatkan sebesar $70,9 \%\left(\mathrm{R}^{2}=0,709\right)$, menunjukkan bahwa self efficacy dan 
openness memiliki pengaruh terhadap perilaku kerja inovatif sebesar 70,9\%, Kemungkinan temuan ini bisa dijelaskan dari komposisi pegawai di Direktorat Jenderal Otonomi Daerah Kementerian Dalam Negeri Republik Indonesia yang mayoritas berada dalam golongan kerja III (Penata) dengan mayoritas pendidikan terakhir jenjang S2. Artinya, pekerja mampu untuk menampilkan perilaku kerja inovatif yang ditunjang oleh keyakinan atas kemampuan yang dimilikinya serta menyukai perubahan sebagai salah satu elemen penting untuk meningkatkan semangat inovasi.

\section{KESIMPULAN}

Hasil penelitian menunjukkan bahwa terdapat pengaruh self efficacy dan openness terhadap perilaku kerja inovatif pada sampel penelitian. Berdasarkan temuan penelitian, saran metodologis yang peneliti ajukan bagi penelitian selanjutnya yaitu disarankan untuk menyertakan gambaran tambahan responden, yang merupakan faktor-faktor pendukung perilaku kerja inovatif, untuk dijadikan kontrol terhadap penelitian. Mengingat bentuk inovasi pada tiap tipe organisasi berbeda-beda. Instansi pemerintahan memiliki formalisasi dan sentralisasi yang tinggi, tentunya akan mempengaruhi pekerja saat menampilkan perilaku inovatifnya. Sebagai tambahan bagi instansi pemerintahan, sarana bagi para pekerja untuk dapat mengaplikasikan atau menerapkan pemikiran inovatifnya sangat diperlukan. Hal ini dapat dilakukan misalnya dengan membuat program kompetisi inovasi. Selain itu, instansi pemerintahan perlu memberikan feedback terkait kinerja pegawai yang berpeluang sebagai pengembangan karir. Penelitian lebih lanjut diharapkan memperluas lingkup populasi dan sampel guna mendorong kesiapan pekerja dalam menjalankan revolusi industri 4.0 dan menuju era society 5.0

\section{UCAPAN TERIMA KASIH}

Penelitian ini dapat dilaksanakan dengan baik berkat bantuan dari berbagai pihak. Oleh karena itu, penulis mengucapkan terima kasih kepada Badan Penelitian dan Pengabdian Masyarakat (BPPM) Fakultas Ilmu Sosial dan Ilmu Politik Universitas Brawijaya yang telah mendanai serta memfasilitasi penulis dalam proses perizinan penelitian. Selain itu, penulis juga mengucapkan terimakasih kepada Direktur Jenderal Otonomi Daerah Kementerian Dalam Negeri Republik Indonesia (Drs. Akmal Malik, M.Si.), seluruh pejabat struktural, dan JFU di lingkungan Direktorat Jenderal Otonomi Daerah Kementerian Dalam Negeri Republik Indonesia yang telah memberikan kesempatan dan izin kepada penulis untuk mengambil data.

\section{DAFTAR PUSTAKA}

Abdullah, I., Omar, R., \& Panatik, S.A. (2016). A literature review on personality, creativity, and innovative behavior. International Review of Management and Marketing. 6(1), 177182.

Andhika, L.R. (2017). Systematic Review: Budaya Inovasi Aspek Yang Terlupakan Dalam Inovasi Kepegawaian. Civil Service. 11(1), 49-61.

Bandura, A. (1995). Self-efficacy in changing societies. Cambridge, UK: Cambridge University Press.

Berry, J. M., \& West, R. L. (1993). Cognitive self-efficacy in relation to personal mastery and goal setting across the life span. International Journal of Behavioral Development, 16(2), 351379. https://doi.org/10.1177/016502549301600213 
Born, A., Schwarzer, R., \& Jerusalem, M. (1995). Indonesian Adaptation of the General SelfEfficacy Scale. Website. http://userpage.fu-berlin.de/ health/indonese.htm

Carmeli, A., \& Schaubroeck, J. (2007). The influence of leaders' and other referents' normative expectations on individual involvement in creative work. The Leadership Quarterly, 18(1), 35-48. https://doi.org/10.1016/j.leaqua.2006.11.001

Chen, I-S. (2016). Examining the linkage between creative self-efficacy and work engagement: The moderating role of openness to experience. Baltic Journal of Management. 11(4), 516-534.

Chen, S.C., Wu, M.C., Chen, C.H. (2010). Employee's personality traits, work motivation and innovative behavior in marine tourism industry. Journal of Service Science and Management, 3(2), 198.

Costa, P. T., \& McCrae, R. R. (1992). Four ways five factors are basic. Personality and Individual Differences. 13(6), 653-665.

Costa, P. T., \& McCrae, R. R. (1988). Personality in adulthood: A six-year longitudinal study of self-reports and spouse ratings on the NEO Personality Inventory. Journal of Personality and Social Psychology, 54(5), 853-863. https://doi.org/10.1037/00223514.54.5.853

De Jong, J. \& Den Hartog, D. (2010). Measuring innovative work behavior. Creativity and Innovation Management, 19(1), 23-36. https://doi.org/10.1111/j.14678691.2010.00547.x

De Jong, J. \& Kemp, R. (2003). Determinants of co-workers' innovative behaviour: An investigation into knowledge intensive services. International Journal of Innovation Management, 7(2), 189-212.

Etikariena, A., \& Muluk, H. (2014). Correlation between Organizational Memory and Innovative Work Behavior. Makara Human Behavior Studies In Asia, 18(2), 77-88. DOI:10.7454/mssh.v18i2.3463

George, J. M., \& Zhou, J. (2001). When openness to experience and conscientiousness are related to creative behavior: an interactional approach. Journal of applied psychology, 86(3), 513.

Ghozali, I. (2013). Aplikasi analisis multivariate dengan program IBM SPSS 21: update PLS Regresi, $7^{\text {th }}$ edition.

Hammond, M. M., Neff, N. L., Farr, J. L., Schwall, A. R., \& Zhao, X. (2011). Predictors of individual-level innovation at work: A meta-analysis. Psychology of Aesthetics, Creativity, and the Arts, 5(1), 90-105. https://doi.org/10.1037/a0018556.

Hodgetts, R. M., \& Luthans, F. (1991). International business enterprises: Management; Case studies. New York, NY: McGraw-Hill.

Hsieh, H.L., Hsieh, J.R., \& Wang, I.L. (2011). Linking personality and innovation: The role of knowledge management. World Transactions on Engineering and Technology Education, 9(1), 38-44.

Janssen, O., Van de Vliert, E. \& West, M. (2004). The bright and dark sides of individual and group innovation: a special issue introduction. Journal of Organizational Behavior. 25(2), 129-145.

Janssen, O. (2000). Job demands, perceptions of effort-reward fairness, and innovative work behavior. Journal of Occupational and Organizational Psychology, 73, 287-302

Judge, T.A., Jackson, C.L., Shaw, J.C., Scott, B.A., \& Rich, B.L. (2007). Self-efficacy and work related performance: the integral role of individual differences. Journal of Applied Psychology, 92(1), 107-127. 
Kleysen, R. F., \& Street, C. T. (2001). Toward a multi-dimensional measure of individual innovative behavior. Journal of intellectual Capital. 2(3), 284-296.

Matzler, K., Renzl, B., Mooradian, T., von Krogh, G., \& Mueller, J. (2011). Personality traits, affective commitment, documentation of knowledge, and knowledge sharing. The International Journal of Human Resource Management, 22(2), 296310. https://doi.org/10.1080/09585192.2011.540156

Messmann, G., \& Mulder, R. H. (2012). Development of a measurement instrument for innovative work behaviour as a dynamic and context-bound construct. Human Resource Development International, 15(1), 43-59. doi:10.1080/13678868.2011.646894

Michael, L.A.H., Hou, S. \& Fan, H. (2011). Creative self-efficacy and innovative behavior in a service setting: optimism as a moderator. Journal of Creative Behavior, 45(4), 258272.

Momeni, M., Ebrahimpour, H., \& Ajirloo, M.B. (2014). The effect of employees' self-efficacy on innovative work behavior at social security organization employees in Ardabil province. Kuwait Chapter of Arabian Journal of Business and Management Review. 3(8), 29-32.

Nijenhuis, K. (2015). Impact Factors For Innovative Work Behavior in The Public Sector. Master Thesis. University of Twente.

Olakitan, O.O. (2011). An examination of the impact of selected personality traits on the innovative behavior of entrepreneurs in Nigeria. International Business and Management, 3(2), 112-121.

Ramdhani, N. (2012) Adaptasi Bahasa dan Budaya Inventori Big Five. Jurnal Psikologi, 39 (2), 189-207.

Scholtz, U. dkk. (2002). Is General Self-Efficacy a Universal Construct? Psychometric Findings from 25 Countries. European Journal of Psychological Assessment, 18(3). 242251.

Turgut, E., \& Sökmen, A. (2018). The effects of perceived organizational ethics on innovative work behavior: Self efficacy's moderating and mediating role. Turkish Journal of Business Ethics, 11, 43-67. http://dx.doi. org/10.12711/tjbe.2018.11.1.0007

Wilson-Evered, E., Härtel, C.E.J. and Neale, M. (2001). A longitudinal study of work group innovation: The importance of transformational leadership and morale. Advances in Health Care Management (Advances in Health Care Management). 2. 315340. https://doi.org/10.1016/S1474-8231(01)02032-8.

Zahra, T.T., Ahmad, H.M., \& Waheed, A. Impact of Ethical Leadership on Innovative Work Behavior: Mediating Role of Self-Efficacy. Journal of Behavioral Sciences. 27 (1), 93107. 